\title{
O Constitucionalismo de Valores
}

\section{Sabrina Piccoli Maroues}

\section{INTRODUÇÃO}

O constitucionalismo de valores é expressão que diz respeito ao direito constitucional do segundo pós-guerra, período histórico em que o mundo, ressurgindo das cinzas, percebeu Que a reconstrução da ordem política democrática deveria ser realizada sobre bases completamente distintas daquelas existentes até então.

O presente trabalho visa, portanto, a analisar este período, bem como seus reflexos no direito constitucional brasileiro.

No primeiro capítulo, buscamos definir a era do constitucionalismo de valores e as alterações havidas no direito constitucional. Para isso, trouxemos o sentido dos valores e a importância da existência de um efetivo sistema de defesa destes valores para assegurar a permanência de um Estado Democrático de Direito. Apresentamos, ainda, o Tribunal Constitucional como o grande órgão de defesa e concreção dos valores supremos do ordenamento.

No segundo capítulo, almejamos demonstrar o ingresso do Brasil na era do constitucionalismo de valores. Assim, embora escassa, apresentamos a visão da doutrina brasileira acerca do tema. Demonstramos também a forma - talvez um pouco tortuosa - com Que o Brasil desenvolveu o constitucionalismo de valores e realizamos algumas críticas.

Evidentemente, este artigo não visa a esgotar o tema, mas fomentar a discussão acerca da defesa dos valores e da Constituição, buscando trazer algumas contribuições. 


\section{A ERA DO CONSTITUCIONALISMO DE VALORES}

\subsection{Sentido dos Valores}

Historicamente, o Direito apresentou-se, reiteradas vezes, como o grande instrumento de dominação do Estado, albergando e justificando inúmeras inieüidades, porquanto, nestes períodos, a lei apenas era considerada em seu aspecto lógico-formal, sem Qualquer incidência valorativa. Esvaziando-se do Direito o seu conteúdo valorativo, abre-se espaço para que o Estado se torne opressor, uma vez que, sob o abrigo da lei, poderá impor Qualquer sorte de comportamento ou de padrões morais.

Um dos momentos históricos em Que a expressão de tal dominação ocorreu de forma mais nítida foi no período entre guerras. As experiências totalitárias (nazismo, fascismo, comunismo) e as barbáries cometidas na Segunda Grande Guerra por todas as partes beligerantes banalizaram a vida e agrediram de tal forma a consciência mundial que a humanidade viu-se diante da necessidade de Que a proteção do homem não garantisse apenas o direito de que ele permanecesse vivo, mas também de que o pudesse fazer com dignidade. Demonstrou-se eue toda forma de desumanização não atinge apenas uma pessoa, mas toda a humanidade representada em cada homem. ${ }^{1} \mathrm{O}$ sofrimento como matriz da compreensão do mundo e dos homens levou a humanidade a perceber, mais do Que em Qualeuer outra época da história, o valor supremo da dignidade humana. ${ }^{2}$

Foi, pois, neste contexto histórico, Que teve início a era do constitucionalismo de valores. Afigurava-se uma exigência Que a reconstrução da ordem política democrática garantisse "um núcleo de valores mínimos, reconhecidos e institucionalizados por consenso"3, os Quais são inerentes à dignidade da pessoa humana e objetivam, primordialmente, repelir as anteriores experiências de violações aos direitos humanos demonstradas, na primeira metade do século XX, pelos regimes totalitários na Europa. A dignidade da pessoa humana, pois, foi alçada a objetivo supremo do Estado, merecendo ampla proteção do direito constitucional, eue a acolheu como fundamento e finalidade. ${ }^{4}$

1 ROCHA, Cármen Lúcia Antunes. O Princípio da Dignidade da Pessoa Humana e a Exclusão Social. nntetesse Público: órgão nacional de doutrina, jurisprudência, legislaçăo e crítica judiciária. São Paulo, ano 1, n. 4, p. 23-48, out./dez. 1999.

2 COMPARATO, Fábio Konder. A Afirmação História dos Direitos Humanos. 2, ed. Săo Pauto: Saraiva, 2001, p. 54.

3 SOUZA IR., Cezar Saldanha. O Tribunal Constitucional como Poder. Uma nova teoria da divisão dos poderes. São Paulo: Mcmória lurídica Editora, 2002, p. 102.

4 SOUZA IR., Cezar Saldanha. O Tribunal Constitucional como Poder. Uma nova teoria da divisão dos poderes. São Paufo: Memória lurídica Editora, 2002, p. 106. 
Assim, após a negação e o desprezo pelos direitos humanos demonstrados no âmbito dos Estados totalitários, surge a Declaração Universal dos Direitos Humanos das Nações Unidas de 1948, dando início ao constitucionalismo de valores, ao processo de conscientização jurídica universal da necessidade de direitos, liberdades e garantias da pessoa humana. ${ }^{5}$

A Declaração Universal dos Direitos do Homem constitui a prova de Que "um sistema de valores pode ser considerado humanamente fundado e, portanto, reconhecido: $\mathrm{e}$ essa prova é o consenso geral acerca da sua validade. " ${ }^{\text {O }}$ valores justificam-se no consenso, ou seja, são tanto mais fundados Quanto mais são aceitos. A Declaração Universal representa um fundamento histórico e, como tal, não absoluto, mas é o único Que pode ser objietivamente comprovado. Foram declarados, explicitamente, Quais os valores universalmente eleitos para reger o futuro de todos os homens. Tem-se, portanto, pela primeira vez na história, um sistema de princípios fundamentais da conduta humana expressamente aceito pela maioria dos homens da Terra, por meio da assinatura de seus governantes.'

O núcleo de valores mínimos que serve à dignidade da pessoa humana é representado. em cada período histórico, de maneira mais concreta, por meio dos direitos fundamentais. Os direitos fundamentais de nossa época constituem a forma de entender nossa sociedade e de relacioná-la com os valores. ${ }^{8} \mathrm{O}$ sentido da dignidade da pessoa humana exige Que direitos sejam afirmados, tanto os direitos de umas pessoas perante as outras Quanto os direitos perante o Estado. Trata-se de direitos universais, pertencentes à pessoa pelo simples fato de ser pessoa, mas que dependem de uma estrutura de poder adequada à sua salvaguarda. ${ }^{\text {" }}$

A dignidade humana, portanto, não depende de Qualquer merecimento pessoal ou social, uma vez Que ela é inerente à vida. Assim, embora o sistema normativo não a constitua, deve reconhecê-la como matriz de toda a organização social e princípio do ordenamento, criando garantias para seu respeito e eficácia. ${ }^{10}$

5 MIRANDA, lorge. O Homem e o Estado - Direitos do Homem e Democracia. Interesse Público: órgăo nacional de doutrina, jurisprudência, legislação e crítica judiciária, São Paulo, ano 1. n. I. p. 79-84, jan./mar. 1999.

- BOBBio, Norberto. A era dos direitos. Tradução Carlos Nelson Coutinho. Rio de laneiro: Campus, 1992, p. 26.

7 BOBBIO, Norberto. A era dos direitos. Traduçăo Carlos Nelson Coutinho. Rio de laneiro: Campus, 1992, p. 26-28.

\& VALORES Juridicos y Derechos Fundamentales. Sevilha: Editorial Mad, 1999.

? MIRANDA, Iorge. O Homem e o Estado -.- Direitos do Homem e Democracia. Interesse Público: órgão nacional de doutrina, jurisprudência, legislação e crítica judiciária, São Paulo, ano I, n. 1, p. 79-84, jan./mar. 1999.

10 ROCHA, Cármen Lúcia Antunes. O Princípio da Dignidade da Pessoa Humana e a Exclusão Social. Interesse Público: órgão nacional de doutrina, jurisprudência, legislação e crítica judiciária, São Paulo, ano I, n. 4, p. 23-48, out./dez. 1999. 
Com efeito, a realização da condição humana não é tarefa de esforço individual, requerendo Que a organização das estruturas políticas, jurídicas, sociais, culturais e econômicas estejam também voltadas para esse fim. Por conseguinte, em cada país, levando-se em consideração as experiências éticas próprias vividas, são eleitos valores Que o Direito deve realizar para servir à dignidade da pessoa humana. Esta é, pois, a justificação dos valores superiores. O núcleo de valores mínimos não advém de arbitrariedade, mas de um acordo social Que possui a pretensão de Que a organização da vida social favoreça, aprofunde e desenvolva a dignidade da pessoa humana. Há um consenso básico de Que tais valores são os mais importantes para a consecução dos objetivos do Estado. A dignidade humana é o fundamento e a razão da necessidade dos valores superiores, sendo estes os caminhos para torná-la real e efetiva."

Assim, o Estado Social do segundo pós-guerra surgiu de um consenso sobre valores éticos mínimos. A reconstrução da democracia calcou-se na afirmação do Direito como um nível fundamental Que não pode ser desligado de valores. A nova ordem, visando a se precaver das terriveis experiências da ordem anterior, fez Questão de mostrar que o Direito é uma concreção de valores, Que o conteúdo ético mínimo do Direito deve ser guardado e preservado. Nesta fase, a Constituição deixou de ser apenas a lei Que regula o político para adeuirir um caráter de sobre-direito, de lei suprema de todo o ordenamento jurídico. Conforme Cezar Saldanha Souza Junior, a Constituição sem deixar de ser a lei reguladora da vida política, deveria aspirar agora à elevada condição de: (a) repositório das normas jurídicas supremas; (b) fundamento de validade de todo o ordenamento jurídico; (c) cabeça de capítulo de todos os ramos do direito; e (d) paradigma para a conformação de todas as normas infraconstitucionais, sob pena de invalidade. ${ }^{12}$

Os tópicos fundamentais da Constituição passaram a ser os valores, princípios ou dimensões normativo-jurídicos, formando o núcleo material da Constituição. ${ }^{13}$ Os valores assumiram um lugar primordial, representando a norma básica material da Constituição. Embora se esteja tratando de direito positivo - o Que confere aos valores o caráter de obrigatoriedade -, o conteúdo dos valores superiores não se esgota na perspectiva normativa, uma vez Que suas raízes estão no campo da moral, da Qual continua a sofrer pressões para ampliar e aprofundar seu sentido. Trata-se, portanto, de conceitos abertos, dando margem à interpretação de juizes e legisladores ordinários. Os valores são, ainda, a expressão da moral aceita, no âmbito cultural e no momento histórico de uma nação, para representar os objetivos máximos a serem desenvolvidos pelo ordenamento jurídico, servindo também de guia para

If PECES-BARBA, Gregorio. Los Valores Superiores. I. ed. Madri: Editorial Tecnos, 1984, p. 111 . 112,43 e $85-86$.

32 SOUZA IR., Cezar Saldanha. O Tribunal Constitucional como Poder. Uma nova teoria da divisão dos poderes. Săo Paulo: Memória Iurídica Editora, 2002, p. 104-105.

${ }^{13}$ CARVALHO, Virgílio de lesus Miranda. Os valores constituclonais fundamentais: Esboço de uma análise axiológico-normativa. Coimbra: Coimbra Editora, 1982, p. 8. 
a interpretação e o desenvolvimento desse ordenamento. Na perspectiva ético-jurídica, convertem-se em elementos identificadores de um Estado Social e Democrático de Direito, representando a necessária distinção de regimes anteriores, mormente os totalitários. Constituem, pois, a faceta jurídica, o conteúdo de justiça material da organização política, ou seja, do Estado Social e Democrático de Direito. ${ }^{1.4}$

Com a inserção de valores na Constituiçăo, reconhece-se a existência de conteúdos materiais no ordenamento, dando novas nuances ao rígido formalismo kelsenjano Que o considerava apenas como conjunto de poderes e de deveres. Não se está, pois, a superar a formalismo normativista, mas a completá-lo com a norma básica material constitucional representada pelos valores superiores. Ademais, esta interpretação afasta a teoria daQueles Que enxergam o Direito apenas como a regulação do uso da força, uma vez Que também estabelece critérios básicos para as condutas Que o Direito regula. Por conseguinte, a inclusão do conceito de valores superiores serve de argumento a amparar a visão de Que o Direito é formado por normas de conduta e também por normas Que regulam o uso da força, sem Que seja necessário optar por uma ou outra alternativa. ${ }^{15}$

\subsection{Defesa dos Valores - O Tribunal Constitucional}

Os valores mínimos concretizados nos direitos universais relativos à dignidade da pessoa humana, embora proclamados e consensualmente reconhecidos, dependem de um efetivo sistema de proteção Que os resguarde dos arbítrios individuais, bem como os defenda do próprio Estado. Há necessidade, portanto, de proteção em nível internacional e de defesa no âmbito interno de cada Estado. ${ }^{16}$

Foi a falta de um sistema de defesa de valores que interrompeu, precocemente, a evolução da Constituição de Weimar. A Constituição Alemã de 1919 representou um marco por sua declaração de direitos, inclusive dos novos direitos sociais; todavia, pela ausência de mecanismos de defesa da Constituição e da ordem constitucional, permitiu a destruição da democracia e do Estado de Direito pelos ataques dos ideologismos nazistas antidemocráticos ${ }^{17}$, o Que acabou por acarretar o adiamento da plena realização da própria Constituição.

Com efeito, após os horrores da Segunda Guerra Mundial, os alemães retomaram sua caminhada constitucional, elencando, na Lei Fundamental de Bonn, de 23 de maio de 1949, a dignidade da pessoa humana como o valor de todos os valores. Na mesma esteira, aderindo ao constitucionalismo de valores, são elaboradas as Constituiçōes da França e da Itália. ${ }^{18}$

\footnotetext{
it PECES-BARBA, Gregorio. L.os Valores Superiores. 1. ed. Madri: Editorial Tecnos, 1984, p. $41-44$ e 65.

is PECES-BARBA, Gregorio. Los Valores Superiores. 1. ed. Madri: Editorial Tecnos, 1984, p. 55-56.

16 MOTTA. Paulo Roberto Ferreira. Direito e Moral: Qual o conteúdo para a Constituiçăo? Revista de Direito Administrativo e Constitucional, Curitiba, ano 2, n. 8, p. 173-180, 2001.

17 SOLZA IR., Cezar Saldanha. A Supremacia do Direito no Estado Democrático e seus Modelos Básicos. Porto Alegre: 2002, p. 163.

18 SOUZA IR. Cezar Saldanha. A Supremacia do Direito no Estado Democrático e seus Modelos Básicos. Porto Alegre: 2002, p. 35.
} 
A dignidade da pessoa humana só encontra eficácia material no Estado Social e Democrático de Direito, e este existe para defendê-la. ${ }^{19}$ Chama-se de Estado de Direito o Estado no qual existe um sistema de garantias dos direitos do homem, bem como mecanismos de defesa de tais direitos e dos valores superiores que os amparam. Evidentemente, portanto, nos Estados não de direito, estão os cidadãos que mais necessitam de proteção, devendo tal proteção ser internacional. Infelizmente, todavia, ainda não alcançamos dito estágio de defesa, uma vez que o Estado Que despreza, internamente, os direitos do homem também é aquele que apresenta escasso respeito às autoridades internacionais. ${ }^{20}$

No nível interno, no sistema democrático, os valores superiores são desenvolvidos em dois planos. Inicialmente, o Poder Legislativo, principal representante da soberania do povo de uma nação, possui o mais importante papel para o desenvolvimento dos valores, porquanto, na tarefa de elaboração das leis, irá buscar a definição concreta dos valores. No segundo plano, encontra-se o Tribunal Constitucional, Que será o responsável por "cuidar" dos valores, Quando houver a necessidade, em alguns casos, de retificar a visão do Poder Legislativo. ${ }^{2}$ Esta necessidade surge, Quando a sociedade precisa se proteger da própria lei, porque, por motivos diversos, a lei não está manifestando a vontade do povo, mas, em verdade, está desrespeitando princípios e direitos fundamentais básicos, com o intuito de favorecimento de algum poderoso grupo de pressão. ${ }^{22}$

Cumpre sinalar Que a jurisdição constitucional não fere o princípio democrático, embora possa declarar a nulidade de leis elaboradas pelos representantes populares, poreuanto a legitimidade para que assim proceda é retirada da Constituição. Considerando Que o poder constituinte originário deu ao Tribunal Constitucional tal poder, presume-se Que o próprio povo elegeu como uma necessidade a proteção do Estado de Direito e dos direitos fundamentais por meio do exercício de uma jurisdição constitucional, entendendo, pois, necessária tal restrição. ${ }^{23}$

Gregorio Peces-Barba visualiza três funções de Que está encarregada a Constituição: função de legitimação, função de justiça e função de segurança, relacionando-se somente as duas primeiras com os valores superiores, razão por Que somente as mencionaremos. A função de legitimação atribui à Constituição à missão de assegurar a obediência ao Direito, sem que seja necessário recorrer à força. A Constituição expressa, para a cultura moderna, a forma racional de poder e de consenso que a aceita como as regras do jogo. Assim, a

12 MOTTA, Paulo Roberto Ferreira. Direito e Moral: Qual o conteúdo para a Constituição? Revista de Direito Administrativo e Constitucional, Curitiba, ano 2, n. 8, p. 173-180, 2001.

20 BOBBIO, Norberto. A era dos direitos. Tradução Carlos Nelson Coutinho. Rio de Janeiro: Campus, 1992, p. $37-41$.

2PECES-BARBA, Gregorio. Los Valores Superiores. I. ed. Madri: Editorial Tecnos, 1984, p. 81-86.

${ }^{22}$ MORAES, Alexandre de. Legitimidade da Justiça Constitucional. Disponível em: <http:// www.netllash.com.br/justicavirtual/artigos/const.htm>. Acesso em: 2 lde abril de 2005.

${ }^{23}$ MORAES, Alexandre de. Legitimidade da Justiça Constitucional. Disponível em: <http:// www.netllash.com.br/justicavirtual/artigos/const.htm>. Acesso em: 2 I de abril de 2005. 
incorporação de conteúdos materiais às Constituições amplia a função de legitimidade também a estes fatores, porque se supõe que houve um acordo social sobre os objetivos do ordenamento. sobre o conteúdo da moralidade, assegurando a obediência ao Direito. Os valores superiores dão boas razões para se obedecer ao Direito, uma vez que o ordenamento vai realizá-los como objetivos máximos. Por sua vez, a função de justiça da Constituição consiste na fixação dos conteúdos de moralidade do Direito, eneuanto os valores superiores explicitam o conteúdo da função de justiça da Constituição. Assim, limitam o arbítrio judicial na busca da definição de tal conteúdo, porquanto os tribunais (inclusive o Constitucional) devem partir dos valores superiores positivados na Constituição. O ponto de partida da função de justiça da Constituição está numa norma de direito positivo superior: a Constituição. A formulação explícita dos valores superiores dá à função de justiça maior objetividade e limita a liberdade de legisladores ordinários e juízes na construção do conteúdo material do ordenamento. ${ }^{24}$

O Tribunal Constitucional é o instrumento mais evoluído de controle de constitucionalidade, sendo essencial para Que se possa falar em supremacia do Direito. Todavia, para que possa cumprir seu papel, é mister Que seja um órgão independente, especializado e concentrador da jurisdição constitucional. Kelsen foi o grande idealizador e delensor do Tribunal Constitucional como guarda da Constituição e, ao rebater as objeções de Schmitt à sua tese, na célebre polêmica entre os dois juristas, frisou Que o Tribunal Constitucional não deve integrar o Poder Judiciário, mas constituir-se em um poder político independente de todos os demais poderes. Assim, evita-se que questóes de alto teor de politicidade sejam decididas pelo Poder Judiciário, o Que, segundo Schmitt - neste ponto com a concordância de Kelsen-, destruiria o Estado de Direito. ${ }^{25}$

Cezar Saldanha Souza Junior propõe três perspectivas para que se concebam as funçôes do Tribunal Constitucional: a instrumental, a formal e a material. ${ }^{26}$

Quanto à perspectiva instrumental, o Tribunal Constitucional desempenha função de natureza jurisdicional, somente se pronunciando Quando instado a se manifestar. Para tal, utilizase dos recursos da hermenêutica jurídica e submete se às imposições do devido processo legal ${ }^{27}$

No Que pertine à natureza formal de suas funçôes, o Tribunal Constitucional desempenha atividade legislativa, criando direito. Em geral, as deliberações são em abstrato, possuindo, por conseqüência, eficácia erga omnes e ex tunc, além de vincular o Poder Judiciário, o Governo, a Administração e, em determinados casos, o Parlamento. ${ }^{28}$

\footnotetext{
24 PECES-BARBA, Gregorio. Los Valores Superiores. I. ed. Madri: Editorial Tecnos, 1984, p. 66-73.

${ }^{25}$ SOUZA IR., Cezar Saldanha. O Tribunal Constitucional como Poder. Uma nova teoria da divisão dos poderes. São Paulo: Memória lurídica Editora, 2002, p. 110-115.

26 SOUZA IR., Cezar Saldanha. O Tribunal Constitucional como Poder. Uma nova teoria da divisão dos poderes. São Paulo: Memória Jurídica Editora, 2002, p. 118.

27 SOUZA IR., Cezar Saldanha. O Tribunal Constitucional como Poder. Uma nova teoria da divisão dos poderes. São Paulo: Memória lurídica Editora, 2002, p. 122.

28 SOUZA IR., Cezar Saldanha. O Tribunal Constitucional como Poder. Uma nova teoria da divisão dos poderes. São Paulo: Memória Iurídica Editora, 2002, p. 122.
} 
No Que diz respeito à perspectiva material, atua o Tribunal Constitucional, juntamente com o Chefe de Estado, no plano da "função política de última instância". O desempenho dessa atividade dar-se-á em relação aos valores superiores, aos fins últimos do Estado. A partir do momento em Que as constituiçōes passaram a albergar valores mínimos, inviabilizouse a atuação do Chefe de Estado como único guardião da Constituição. Fez-se necessária a criação de um órgão colegiado especificamente voltado para esse fim, constituído por membros minuciosamente escolhidos, dominando técnicas jurídicas adequadas. Na natureza funcional material, sua atuação poderia ser assim arrolada:

(a) renovar, continuamente, o consenso político Que sustenta a ordem democrática instituída na Constituição; (b) atualizar, incessantemente, o poder constituinte originário, tanto na concreção dos valores supremos do ordenamento, Quanto na necessária evolução diante das novas exigências da história e da consciência da civilização; (c) arbitrar, Quando envolvida Questão constitucional, conflitos entre poderes, tanto na distribuição funcional, Quanto na distribuição territorial; e (d) proteger os direitos fundamentais da pessoa frente ao poder público e à sociedade em geral. ${ }^{29}$

É na função de natureza material Que o Tribunal Constitucional realiza a importante missão de proteção, defesa e desenvolvimento dos valores superiores. O seu papel será o de construir e renovar um consenso Que esteja acima do plano partidário e ideológico, atuando em um nível em Que "a política e a ética se abraçam, pela mediação dos valores (supremos) do direito". ${ }^{30}$ E é exatamente em função desse "triálogo" realizado entre ética, política e direito, na concreção dos valores superiores, Que o Tribunal Constitucional deve ser um órgão independente do Poder Judiciário, a fim de evitar a politização de tal Poder Que seria ruinosa ao Estado de Direito, conforme já antevisto por Kelsen e Schmitt. ${ }^{31}$

A interpretação constitucional reQuer eQuilibrio entre o jurídico e o político, sendo ambos os planos decisivamente importantes, razão por Que o intérprete constitucional não pode ser somente o jurista, mas aquele Que saiba também conjugar - e na mesma medida o fator político. ${ }^{32}$

No Que tange aos direitos da pessoa humana, embora a maior parte deles seja aceita consensualmente, o seu exercício mostra-se deveras complicado, porquanto não possuem um valor absoluto. Está-se diante de direitos fundamentais relativos, pois sua tutela encontra

2) SOUZA IR., Cezar Saldanha. O Tribunal Constitucional como Poder. Uma nova teoria da divisão dos poderes. São Paulo: Memória lurídica Editora, 2002, p. 118-121.

* SOUZA IR., Cezar Saldanha. A Supremacia do Direito no Estado Democrático e seus Modelos Básicos. Porto Alegre: 2002, p. 92 e 185.

${ }^{3}$ SOUZA IR., Cezar Saldanha. O Tribunal Constitucional como Poder. Uma nova teoria da divisão dos poderes. São Paulo: Memória lurídica Editora, 2002, p. 125.

32 BONAVIDES, Paulo. Curso de Direito Constitucional. 14. ed. Säo Paulo: Malheiros, 2004, p. 463. 
um limite insuperável na tutela de outro direito também fundamental, mas concorrente. Os valores últimos são, por conseguinte, antinômicos. ${ }^{33} \mathrm{~A}$ técnica de ponderaçâo de valores para a resolução de tais problemas não se situa no âmbito deste trabalho. Entretanto, cumpre destacar que se configura em típica tarefa a ser executada pelo Tribunal Constitucional, uma vez Que a ele cabe concretizar os valores supremos do ordenamento.

\section{O BRASIL NA ERA DO CONSTITUCIONALISMO DE VALORES}

\section{1 a Visão da Doutrina Brasileira}

Inicialmente, cumpre consignar Que, na doutrina brasileira, não encontramos outro autor, além de Cezar Saldanha Souza Junior, Que intitule de "constitucionalismo de valores" o direito constitucional do segundo pós-guerra. Ademais, também são raros os doutrinadores Que tratem, ainda Que sob outras denominações, acerca do ingresso do Brasil na era do constitucionalismo de valores.

Segundo Cezar Saldanha Souza Junior, a promulgação da Constituição da República Federativa do Brasil, de 5 de outubro de 1988, marca o ingresso do país na era do constitucionalismo de valores, ao declarar, no artigo $1^{\circ}$, III, a dignidade da pessoa humana como fundamento do Estado e, no artigo $3^{\circ}$. IV a promoção do bem de todos como objetivo fundamental.$^{34} \mathrm{~A}$ Constituição, demonstrando sintonia com a evolução do direito ocidental, proclamou diversos avanços, como

(a) multiplicação das cláusulas gerais e dos princípios indeterminados; (b) fundamentação da vida juruídica em noções de altíssima densidade poítica, tais como, a dignidade da pessoa humana, justiça e função social, razoabilidade e tantas outras; (c) ampliação do acesso ao poder judiciário ao ser humano comum; (d) extensão da legitimidade, para entidades coletivas privadas e, mesmo, a órgãos públicos, para ações de profundo alcance político; e (e) principalmente, a previsão de instrumentos de controle direto de constitucionalidade relativamente $\mathrm{a}$ atos normativos em abstrato. ${ }^{35}$

Cármen Lúcia Antunes Rocha destaca que, se não fosse Auschwitz, talvez a dignidade da pessoa humana não fosse ainda o princípio-matriz do constitucionalismo contemporâneo. Todavia, tendo o homem vivido o Holocausto, fez-se necessário evitar nova degradação da

33 BOBBIO, Norberto. A era dos direitos. Traduçăo Carlos Nelson Coutinho. Rio de laneiro: Campus, 1992, p. 42-44.

34 SOUZA JR., Cezar Saldanha. Constituições do Brasil. Porto Alegre: Sagra Luzzatto, 2002, p. 86.

35 SOUZA IR., Cezar Saldanha. O Tribunal Constitucional como Poder. Uma nova teoria da divisăo dos poderes. Săo Paulo: Mernória lurídica Editora, 2002, p. 137. 
pessoa por outras que possam destruí-la ao chegar ao poder. Frisa a autora Que, no Brasil, o princípio da dignidade da pessoa humana comparece de maneira inédita na Constituição de 1988, vindo a modificar toda a construção jurídica, uma vez cue impregna a elaboração do Direito, enquanto elemento fundante da ordem constitucionalizada e posta na base do sistema. A eleição do princípio como fundamento do Estado significa Que esse existe para o homem, Que o seu fim é o homem, "como sujeito de dignidade, de razão digna e supremamente posta acima de todos os bens e coisas, inclusive do próprio Estado". ${ }^{36}$

Luiz Antônio Rizzatto Nunes ressalta oưe, tendo em vista a experiência do genocídio nazista da Segunda Grande Guerra, não é possível falar hoje em sistema jurídico legítimo Que não esteja fundado na garantia da intangibilidade da dignidade da pessoa humana. A partir daQuela ocorrência, foi erigida uma nova razão ético-jurídica-universal. No atual Dịploma Constitucional brasileiro, é a dignidade da pessoa humana o primeiro fundamento de todo o sistema constitucional. Para o autor a dignidade é absoluta, plena e inerente à essência da pessoa. Além disso, é um supraprincípio constitucional que deve ser sempre considerado na atuação social do operador do Direito, uma vez que a própria Constituição impõe a sua implementação concreta. ${ }^{37}$

José Afonso da Silva realça Que fundamentou a positivação constitucional do princípio da dignidade da pessoa humana, na Lei Fundamental da República Federal da Alemanha, as graves violaçōes sofridas pela dignidade humana sob a égide do Estado nazista. Idêntica motivação histórica também fez constar o princípio nas Constituições de Portugal e Espanha. No caso do Brasil, a tortura e toda sorte de desrespeito à pessoa humana praticados na vigência do regime militar levaram à inclusão da dignidade da pessoa humana como fundamento do Estado Democrático de Direito em que se constitui a República Federativa do Brasil, consoante disposto no artigo $1^{\circ}$, III, da Constituição de 1988. Ao constituir a dignidade da pessoa humana como fundamento, consagrou-a como valor supremo, "valor fundante da República, da Federação, do País, da Democracia e do Direito". ${ }^{38}$ Ressalta, ainda, Que a democracia é o único regime político capaz de propiciar a efetividade de todas as dimensões de direitos fundamentais do homem, Quando, então, o homem estará dignificado. Representa, pois, a dignidade da pessoa humana o valor supremo da democracia, o valor Que a dimensiona e humaniza. ${ }^{39}$

Ana Paula de Barcellos evidencia Que as Constituições elaboradas após a Segunda Guerra Mundial expressamente albergaram valores, formularam decisões políticas e fixaram metas e objetivos a serem alcançados pelos Estados que estavam recriando, porquanto

${ }^{36}$ ROCHA, Cármen Lúcia Antunes. O Princípio da Dignidade da Pessoa Humana e a Exclusão Social. Interesse Público: órgão nacional de doutrina, jurisprudência, legislaçãa e crítica judiciária, São Paulo, ano I, n. 4, p. 23-48, oul./dez. 1999.

37 NUNES, Luiz Antônio Rizzatto. O princípio constitucional da dignidade da pessoa humana: doutrina e jurisprudência. Săo Paulo: Saraiva, 2002, p. 25-26, 45-46 e 49-51.

38 SILVA, losé Afonso da. A dignidade da pessoa hurnana como valor supremo da democracia. Revista de Direito Administrativo, Rio de laneiro: Fundação Getúlio Vargas, v. 212, p. 89-94, abr/jun. 1998.

39 SILVA, José Afonso da. A dignidade da pessoa humana como valor supremo da democracia. Revista de Direito Administrativo, Rio de laneiro: Fundação Getúlio Vargas, v. 212, p. 89-94, abr./jun. 1998. 
voltou-se a reconhecer Que o direito não surge no mundo por si só, mas está relacionado a valores prévios, ideais de justiça e de humanidade, os Quais são frutos da consciência humana e da experiência civilizatória dos povos. Sob a forma de normas-princípios, os valores passaram a figurar como núcleo das Constituições, estando expressamente demonstrados quais os valores eleitos pelo constituinte como fundamentais à organização política, bem como os limites, formas e objetivos dirigidos à atuação política do Estado, com a finalidade de promover a realização desses valores. Aduz, ainda, Que a Constituição brasileira de 1988 se insere neste contexto histórico, ao consagrar como fundamento do Estado o homem e sua dignidade, como se observa do artigo ${ }^{\circ}{ }^{\circ}$, Ill, da Carta, e do seu preâmbulo. ${ }^{40}$

Daniel Sarmento expõe que a Constituição brasileira de 1988, seguindo o exemplo de diversas cartas contemporâneas, reconheceu a dignidade da pessoa humana como fundamento da República Federativa do Brasil (artigo 1․, 11I). Assevera, ainda, que essa proclamação solene, no primeiro artigo do texto constitucional, é rica em simbolismo, pois marca a restauração do Estado Democrático de Direito, Qualificado pela preocupação com os direitos humanos e com a justiça social no país. $O$ autor salienta Que o princípio da dignidade da pessoa humana representa o epicentro axiológico da ordem constitucional, irradiando efeitos sobre todo o ordenamento jurídico. ${ }^{41}$

Edson Pereira Nobre Junior refere que o reconhecimento do ser humano como o centro e o fim do Direito marca os ordenamentos atuais, mormente após a barbárie nazifascista, estando tal inclinação demonstrada com a adoção da dignidade da pessoa humana como valor básico do Estado Democrático de Direito. Conforme o autor, o nosso constitucionalismo, Que, desde 1934, vem sofrendo forte influxo germânico, não ticou alheio ao terna, tendo o constituinte de 1988 deixado claro Que o Estado Democrático de Direito Que instituía tem como fundamento a dignidade da pessoa humana (artigo $1^{\circ}$, III). As conseQüências da adoção desse princípio são

a) a reverência à igualdade entre os homens (art. $5^{\circ}, \mathrm{l}, \mathrm{CF}$ ): b) o impedimento à consideração do ser humano como objeto, degradando-se a sua condição de pessoa, a implicar na observância de prerrogativas de direito e processo penal, na limitação da autonomia da vontade e no respeito aos direitos da personalidade, entre os Quais estão inseridas as restriçôes à manipulação genética do homem; c) a garantia de um patamar existencial mínimo. ${ }^{42}$

Paulo Bonavides registra Que o ano de 1948, com a Declaração Universal dos Direitos do Homem das Nações Unidas, foi tão importante para a nova universalidade de

10 BARCellos, Ana Paula de. A eficácia jurídica dos princípios constitucionais: o princípio da dignidade da pessoa humana, Rio de laneiro: Renovar, 2002, p. 20-25.

4 SARMENTO, Daniel. A Ponderação de Interesses na Constituiçăo Federal. Rio de laneiro: Lumen Juris, 2003, p. 57-60.

42 NOBRE JR, Edson Pereira. O direito brasileiro e o princípio da dignidade da pessoa humana. Revista de Direito Administrativo, Rio de laneiro: Fundaçăo Getúlio Vargas, v. 219, p. 237-254. 
direitos fundamentais Quanto o de 1789, com a Declaração dos Direitos do Homem, o fora para a velha universalidade de inspiraçáo liberal, porquanto apresentou ao mundo a carta de valores e princípios sobre os Quais estão assentados os direitos das três geraçôes. Segundo o autor, trata-se de um documento de convergência e síntese, pois convergiu, após a guerra de extermínio dos anos 30 e 40, anseios e esperanças dos povos que o subscreveram, ao mesmo tempo em que sintetizou direitos e garantias Que, isoladamente, nenhuma Constituição havia logrado congregar ao redor de um consenso universal. Esta nova universalidade de direitos fundamentais estaria num grau mais alto de juridicidade, concretude, positividade e eficácia, além de entregar a titularidade dos direitos da trípilice geração a um indivíduo Qualificado por sua pertinência ao gênero humano, antes de ser cidadão deste ou daquele país. ${ }^{43}$

Paulo Bonavides enxerga a evolução constitucional, no Brasil, em três fases, sendo a terceira a que se inicia na década de 30 e na qual se percebe a presença de forte influência do constitucionalismo alemão do corrente século. Nesta terceira época, brotou, no Brasil, um Estado social em que a sociedade e o homem-pessoa são os valores supremos. Destaca, ainda, o autor a grande importância Que os direitos fundamentais receberam na Constituição de 1988, sendo Que, na técnica, na forma e na substância de tal matéria, em muito se acerca da Lei Fundamental de Bonn. ${ }^{44}$

\subsection{O Desenvolvimento do Constitucionalismo de Valores no Brasil}

No Brasil, o controle de constitucionalidade é exercido tanto de forma difusa Quanto concentrada. ${ }^{45}$

Segundo o artigo 102, I, a, da Constituição da República Federativa do Brasil, compete ao Supremo Tribunal Federal, precipuamente, a guarda da Constituição, cabendo-lhe processar e julgar, originariamente, a ação direta de inconstitucionalidade de lei ou ato normativo federal ou estadual e a ação declaratória de constitucionalidade de lei ou ato normativo federal, exercendo, portanto, o controle concentrado de constitucionalidade. ${ }^{46}$

Em linhas gerais, o controle difuso de constitucionalidade caracteriza-se pela permissão de Que todo juiz ou tribunal, no caso concreto, possa deixar de aplicar uma lei, entendendo-a incompatível com a Constituição. Ocorrendo uma das hipóteses previstas nas alíneas do inciso III do artigo 102, as causas decididas em única ou última instância serão levadas a julgamento, mediante recurso extraordinário, ao Supremo Tribunal Federal. ${ }^{47}$

43 BONAVIDES, Paulo. Curso de Direito Constitucional. 14. ed. São Paulo: Malheiros, 2004, p. 573-574.

it BONAVIDES, Paulo. Curso de Direito Constitucional. 14. ed. São Paulo: Malheiros, 2004, p. 361-369.

${ }^{45}$ MORAES, Alexandre de. Direito Constitucional. 9. ed. São Paulo: Atlas, 2001. p. 565.

${ }^{46}$ MORAES, Alexandre de. Direito Constitucional. 9. ed. São Paulo: Atlas, 2001, p. 565.

${ }^{47}$ SILVA, losé Afonso da. Poder Constituinte e Poder Popular. (estudos sobre a Constituição). São Paulo: Malheiros, 2000, p. 255. 
Verifica-se, portanto, Que todos os juízes e os tribunais possuem legitimidade para exercer o controle de constitucionalidade, sendo que o Supremo Tribunal Federal o faz tanto de forma concentrada Quanto difusa. Nesta tarefa, todos eles podem ponderar e desenvolver os valores supremos do ordenamento, não tendo nossa Constituição resguardado esta importante missão à exclusividade de um Tribunal Constitucional. ${ }^{48}$

A primeira crítica Que se pode fazer ao sistema diz respeito ao fato de não constituir o Supremo Tribunal Federal um verdadeiro Tribunal Constitucional. Embora a Constituição Ihe encarregue da função de guarda da Constituição, lhe dá competência simultânea para julgar açōes em controle abstrato e concreto de constitucionalidade, não sendo fácil conciliar ambas as funçôes na tarefa diária do exercício da jurisdiçãa. No mesmo Tribunal, com os mesmos Ministros, desenvolvem-se dois sistemas que possuem técnicas, pressupostos e efeitos completamente diferentes e, em certo sentido, até contraditórios, gerando uma verdadeira confusão. ${ }^{49}$ Dessa forma, como observa losé Afonso da Silva, se o Supremo Tribunal Federal não vier a realizar-se plenamente como guardião da Constituição, não será por sua culpa, mas do próprio sistema Que o constituinte de 1988 the impôs. ${ }^{50}$

Ademais, na ausência de um Tribunal Constitucional para garantir um mínimo de objetividade aos valores superiores do ordenamento, podemos assistir também ao perigo do uso ideológico dos instrumentos jurídicos ${ }^{51}$, porquanto todos os juízes e todos os tribunais podem empregar aos valores o sentido Que desejarem, se assim o desejarem, utilizando-se, por exemplo, de princípios tão em voga como os da proporcionalidade e da ponderação de interesses. E. Schmidt, citado por Paulo Bonavides, critica o emprego do princípio da proporcionalidade, uma vez que representaria uma decisāo de difícil fundamentação Que visa somente a expressar o desejo e a vontade de Quem a toma. ${ }^{52}$ Igualmente, sob o manto da ponderação de interesses, é possível que se pratique o mais puro decisionismo judicial, em Que um conflito entre princípios constitucionais será resolvido com base em preferências subjetivas e não justificadas. ${ }^{53}$ Assim, cada juiz, cada tribunal exerce, a seu modo, o desenvolvimento dos valores supremos do ordenamento. Em verdade, não estamos a crițcar os próprios princípios, mas a utilização indiscriminada de tão importantes princípios por

${ }^{48}$ André Copetti enaltece a posição assumida pelo Poder fudicíáno de concretização da Carta Constitucional. Todavia, o autor somente analisa o papel do STF como (re)construtor e concretizador da Constituição, como se houvesse alguma limitação formal ao exercício de tal tarefa pelos demais órgăos do Poder Judiciário. (COPETrI, André. A Jurisprudencialização da Constituição no Estado Democrático de Direito. Disponível em: hitp://www.hj.org.br/ novo/professores/Professores_06.pdf. Acesso em 21 de abril de 2005.)

49 SOLZA IR., Cezar Saldanha. O Tribunal Constitucional como Poder. Uma nova teoria da divisão dos poderes. São Pauło: Memória lurídica Editora, 2002, p. 140.

so SILVA, Losé Afonso da. Poder Constituinte e Poder Popular. (estudos sobre a Constituição). São Paulo: Malheiros, 2000, p. 255.

st SOUZA IR., Cezar Saldanha. O Tribunal Constitucional como Poder. Uma nova teoria da divisăo dos poderes. Săo Paulo: Memória Jurídica Editora, 2002, p. 140.

52 BONAVIDES, Paulo. Curso de Direito Constitucional. 14, ed. São Paulo: Malheiros, 2004, p. 429.

s3 SARMENTO, Daniel. A Ponderação de Interesses na Constituição Federal. Rio de Janeiro: Lumen Juris, 2003. p. 146. 
todas as instâncias do Poder judiciário, justificando, portanto, toda sorte de decisōes, inclusive aquelas diametralmente opostas.

Quando os juízes estão desenvolvendo, concretizando os valores supremos do ordenamento, estão trabalhando em linguagem tão aberta, indeterminada, plurissignificativa, Que tornam o ato de interpretação constitucional praticamente ilimitado ${ }^{54}$ Assim, a delimitação de noções delicadas e de alta densidade poílítica deveria ter sido destinada a um só órgão - um Tribunal Constituciona! -, mas a Constituição preferiu entregar essa tarefa a todos os juizes e tribunais, gerando grande insegurança jurídica.

O Supremo Tribunal Federal também não se converteu em Corte Constitucional pelo fato de não ser o único órgão competente para o exercício da jurisdição constitucional, conforme já observamos, ${ }^{55}$ Ademais, integra o STF o Poder Judiciário e, juntamente com os demais órgãos deste Poder, na competência que todos detém para o exercício do controle de constitucionalidade, faz com que sintamos, no Brasil, a politização da justiça, já temida, há tantos anos, por Kelsen e Schmitt. Aliás, uma das críticas mais severas que recebe o controle de constitucionalidade exercido por órgão integrante do Poder Judiciário é o fato de o juiz ou tribunal assumir posição eminentemente política. ${ }^{56}$ Isso vem ocorrendo porque o Brasil não percebeu Que a nobre tarefa de concreção dos valores não pode ser entregue ao Poder ludiciário e - pior ainda - a todos os órgãos do Poder |udiciário. O juiz constitucional, em virtude da repercussão de suas decisões, desempenha, necessariamente, um papel ou uma função política. ${ }^{57}$ Portanto, se ele integrar o ludiciário, a politização da justiça será simples conseqüência do desempenho de sua função. ${ }^{58}$

Por isso, afigura-se tão relevante a discussão acerca do tipo de justiça constituciona! incumbida de realizar o controle de constitucionalidade em cada país. O estabelecimento de tribunais Que nâo fazem parte da cúpula do Poder Judiciário instituiu um novo modelo de justiça constitucional - introduzido a partir da Áustria e reafirmado nas Constituições da Itália e da Alemanha -, deixando marcas indeléveis no constitucionalismo contemporâneo. A separação da jurisdiçāo ordinária da jurisdição constitucional deslocou o pólo de tensão relacionado à Questão da invasão do Poder Judiciário no Legislativo, também não havendo mais preocupação Quanto ao acentuado caráter poítico das decisões, uma vez que o Tribunal Constitucional passou a estar organizado fora da estrutura do Poder Judiciário. ${ }^{59}$

54 COELHO, Inocêncio Mártires. A dimensão política da jurisdição constitucional. Revista de Direito Administrativo, Rio de laneiro: Fundação Getúlio Vargas, v. 225, p. 39-44, jul./set. 2001.

55 SILVA, losé Afonso da. Poder Constituinte e Poder Popular. (estudos sobre a Constituição). São Paulo: Malheiros, 2000, p. 255-256.

56 BONAVIDES, Paulo. Curso de Direito Constitucional. 14. ed. São Paulo: Malheiros, 2004, p. $30 \mathrm{l}$.

57 MORAES, Alexandre de. Jurisdiçăo Constitucional e Tribunals Constitucionais. Garantia Suprema da Constituição. São Paulo: Atlas, 2000, p. 289-290.

s8 SOUZA IR., Cezar Saldanha. O Tribunal Constitucional como Poder. Uma nova teoria da divisão dos poderes. Săo Paulo: Memória Jurídica Editora, 2002, p. 140.

59 STRECK, Lenio Luiz. Jurisdição constitucional e hermenêutica: uma nova crítica do direito. Porto Alegre: Livraria do Advogado, 2002, p. 102-103. 
Com a Constituição de 1988, o Brasil ingressou na era do constitucionalismo de valores e apresentou avanços realmente significativos. Entretanto, lamentavelmente, não seguiu, neste ponto, as constituições européias Que the serviram de modelo e não adotou um Tribunal Constitucional ${ }^{60}$, Que seria o órgão apropriado para, efetivamente, desenvolver e concretizar os valores supremos de nosso ordenamento. O constitucionalismo de valores no Brasil, portanto, não restou plenamente desenvolvido, pois somente um Tribunal Constitucional - órgão independente, especializado e concentrador da jurisdição constitucional - cumpriria esse desiderato.

\section{CONCLUSÃo}

As experiências totalitárias da primeira metade do século $X X$ despertaram a consciência mundial acerca do valor supremo da dignidade humana. A partir de então, as constituições passaram a albergar valores éticos mínimos, reconhecidos e institucionalizados por consenso, sendo, pois, superada a visão da lei em seu aspecto meramente lógico-formal.

Com tal consciência, surge a necessidade de existência de um efetivo sistema de proteção dos valores, resguardando-os dos arbítrios individuais e do próprio Estado. É nesse âmbito gue surge o Tribunal Constitucional (órgão independente, especializado e concentrador da jurisdição constitucional), como decorrência lógica do desenvolvimento do constitucionalismo de valores.

O Brasil ingressou na era do constitucionalismo de valores com a Constituição de 1988, albergando a dignidade da pessoa humana como fundamento do Estado. A Constituição trouxe, também, inúmeras cláusulas gerais, princípios indeterminados, nítidos valores a serem desenvolvidos e concretizados por um Tribunal Constitucional. Todavia, a Constituição não institulu esse Tribunal Constitucional, razão por Que o constitucionalismo de valores não restou plenamente desenvolvido no Brasil.

Por conseguinte, permanecemos com a jurisdição ordinária e a jurisdiçẫo constitucional cumuladas no Poder Judiciário, em um sistema Que tenta conjugar técnicas concretas e abstratas de controle de constitucionalidade, mostrando-se ineficaz à concreçăo dos valores supremos do ordenamento. Dessa forma, infelizmente, sentimos, em nosso país, a politização da justiça, porquanto o desempenho da tarefa de interpretação constitucional pressupõe o exercício de função política. Ademais, estando legitimados todos os juízes e tribunais a exercerem o controle de constitucionalidade, exercem todos, a seu modo, a nobre tarefa de proteção e desenvolvimento dos valores, gerando o risco do uso ideológico do direito.

60 STRECK, Lenio Luiz. Jurisdição constitucional e hermenêutica: uma nova crítica do direito. Porto Alegre: Livraria do Advogado, 2002, p. 102-103. 


\section{REFERÊNCIAS BIBLIOGRÁFICAS}

BARCELLOS, Ana Paula de. A eficácia jurídica dos princípios constitucionais: o princípio da dignidade da pessoa humana. Rio de laneiro: Renovar, 2002.

BOBBIO, Norberto. A era dos direitos. Tradução Carlos Nelson Coutinho. Rio de laneiro: Campus, 1992.

BONAVIDES, Paulo. Curso de Direito Constitucional. 14. ed. São Paulo: Malheiros, 2004.

CARVALHO, Virgílio de Jesus Miranda. Os valores constitucionais fundamentais: Esboço de uma análise axiológico-normativa. Coimbra: Coimbra Editora, 1982.

COELHO, Inocêncio Mártires. A dimensāo poítíca da jurisdição constitucional. Revista de

Direito Administrativo, Rio de Janeiro: Fundação Getúlio Vargas, v. 225, p. 39-44, jul./set. 2001.

COMPARATO, Fábio Konder. A Afirmação História dos Dircitos Humanos. 2. ed. São Paulo: Saraiva, 2001.

COPETTI, André. A Jurisprudencialização da Constituição no Estado Democrático de Direito. Disponível em: http://www.ihj.org.br/_novo/professores/ Professores 06.pdf. Acesso em 21 de abril de 2005.

MIRANDA, lorge. O Homem e o Estado - Direitos do Homem e Democracia. Interesse Público: órgão nacional de doutrina, jurisprudência, legislação e crítica judiciária, Săo Paulo, ano 1, n. 1, p. 79-84, jan./mar. 1999.

MORAES, Alexandre de. Direito Constitucional. 9. ed. São Paulo: Atlas, 2001.

MORAES, Alexandre de. Jurisdição Constitucional e Tribunais Constitucionais. Garantia Suprema da Constituição. São Paulo: Atlas, 2000.

MORAES, Alexandre de. Legitimidade da Jusı̇̇ça Constitucional. Disponível em: $<$ http://www.netllash.com.br/justicavirtual/artigos/const.htm>. Acesso em: 21 de abril de 2005.

MOTTA, Paulo Roberto Ferreira. Direito e Moral: Qual o conteúdo para a Constituição? Revista de Direito Administrativo e Constitucional, Curitiba, ano 2, n. 8, p. 173-180, 2001. NOBRE IR, Edson Pereira. O direito brasileiro e o princípio da dignidade da pessoa humana. Revista de Direito Administrativo, Rio de faneiro: Fundação Getúlio Vargas, v. 219. p. 237-254.

NUNES, Luiz Antônio Rizzatio. O princípio constitucional da dignidade da pessoa humana: doutrina e jurisprudência. Säo Paulo: Saraiva, 2002.

PECES-BARBA, Gregorio: Los Valores Superiores. I. ed. Madri: Editorial Tecnos, 1984.

ROCHA, Cármen lúcia Antunes. O Princípio da Dignidade da Pessoa Humana e a Exclusão Social. Interesse Público: órgão nacional de doutrina, jurisprudência, legislação e crítica fudiciária, São Paulo, ano 1, n. 4, p. 23-48, out./dez. 1999.

SARMENTO, Daniel. A Ponderação de Interesses na Constituição Federal. Rio de Janeiro: Lumen Juris, 2003.

SilvA, losé Afonso da. A dignidade da pessoa humana como valor supremo da democracia. Revista de Direito Administrativo, Rio de laneiro: Fundação Getúlio Vargas, v. 2 [2, p. 89-94, abr-jun. 1998.

SILVA, José Alonso da. Poder Constituinte e Poder Popular. (estudos sobre a Constituição). São Paulo: Malheiros, 2000.

SOUZA IR., Cezar Saldanha. A Supremacia do Direito no Estado Democrático e seus Modelos Básicos. Porto Alegre: 2002.

SOUZA IR., Cezar Saldanha. Constituições do Brasil. Porto Alegre: Sagra Luzzatto, 2002.

SOUZA IR., Cezar Saldanha. O Tribunal Constitucional como Poder. Una nova teoria da divisão dos poderes. São Paulo: Memória lurídica Editora, 2002.

STRECK, Lenio Luiz. Jurisdição constitucional e hermenêutica: uma nova crítica do direito. Porto Alegre: Livraria do Advogado, 2002.

VALORES Jurídicos y Derechos Fundamentales. Sevilha: Editorial Mad, 1999. 